PERM JOURNAL OF PETROLEUM AND MINING ENGINEERING

ВЕСТНИК ПНИІУ. ГЕОЛОГИЯ. НЕФТЕААЗОВОЕ И ГОРНОЕ ДЕЈЮ

ISSN 2224-9923

Volume/ Tом 18 №2, 2018

http://vestnik-pstu.ru/geo/

УДК 622.276:552.52.08

Article / Статья

(c) PNRPU / ПНИПУ, 2018

\title{
SORPTION ABILITY OF CLAYS EXPOSED TO COMPRESSION
}

\section{Natalia A. Medvedeva, Olga S. Siteva, Valeriy V. Seredin}

Perm State National Research University (15 Bukireva st., Perm, 614068, Russian Federation)

\section{СОРБЦИОННАЯ СПОСОБНОСТЬ ГЛИН, ПОДВЕРЖЕННЫХ СЖАТИЮ Н.А. Медведева, О.С. Ситева, В.В. Середин}

Пермский государственный национальный исследовательский университет (614068, Россия, г. Пермь, ул. Букирева, 15)

Received / Получена: 10.07.2018. Accepted / Принята: 24.10.2018. Published / Опубликована: 30.11.2018

Key words:

clay, montmorillonite, kaolinite, pressure, specific surface, sorbent, petroleum products, fractional analysis, ion exchange capacity, methylene blue, adsorption, diesel fuel, engine oil, transmission oil, thermogravimetry.

\begin{abstract}
The paper discusses the effect of high pressures on adsorption of inorganic ions $(\mathrm{KCl})$, methylene blue and petroleum products (engine oil, transmission fluid, diesel fuel) by samples of montmorillonite and kaolinite. The relationship between the value of the applied pressure (in the range from 0 to $700 \mathrm{MPa}$ ), fractional composition, specific surface and the microstructure of mineral particles was revealed. During the study, dynamics of changes in the content of the clay, dust and sand fractions in the clays under study was noted. It is established that an increase in clay compression to $700 \mathrm{MPa}$ leads to a decrease in the content of clay fractions and an increase in the fraction of the dust fraction. Changes in the fractional composition occur more intensively in kaolinite clay than in montmorillonite clay. The pressure intervals were determined according to the intensity of the formation of the fractional composition of clays 0-200 and 200-700 MPa. Adsorption parameters of clays are determined. According to potentiometric measurements, it has been established that the ion-exchange capacity is higher in montmorillonite than in kaolinite with in respect to cations. The magnitude of kaolinite adsorption with respect to methylene blue decreases to a pressure of $200 \mathrm{MPa}$, which is caused by the content of the clay fraction, does not change significantly at pressures of 200-700 $\mathrm{MPa}$. The adsorption rate of montmorillonite has a general tendency to increase. Adsorption indicators of clays with respect to methylene blue allow predicting the sorption capacity of the studied materials to petroleum products.
\end{abstract}

\begin{abstract}
Изучено влияние высоких давлений на адсорбцию неорганических ионов $(\mathrm{KCl})$, метиленового голубого и нефтепродуктов (моторное масло, трансмиссионная жидкость, дизельное топливо) образцами монтмориллонита и каолинита. Выявлена взаимосвязь между величиной прикладываемого давления (в интервале от 0 до 700 МПа), фракционным составом, удельной поверхностью и микроструктурой минеральных частиц. В ходе проведенного исследования была отмечена динамика изменения содержания глинистой, пылеватой и песчаной фракций в исследуемых глинах. Установлено, что увеличение сжатия глины до 700 МПа приводит к уменьшению содержания глинистых фракций и увеличению доли пылеватой фракции. В каолиновой глине изменения фракционного состава протекают более интенсивно, чем в монтмориллонитовой глине. Определены интервалы давлений по интенсивности формирования фракционного состава глин 0-200 и 200-700 МПа. Определены адсорбционные параметры глин. Согласно потенциометрическим измерениям установлено, что показатели ионообменной емкости в отношении катионов выше у монтмориллонита, чем у каолинита. Величина адсорбции каолинита по отношению к метиленовому голубому уменьшается до давления 200 МПа, что обусловлено содержанием глинистой фракции, при давлениях 200-700 МПа существенно не изменяется. Показатель адсорбции монтмориллонита имеет общую тенденцию к возрастанию. Адсорбционные показатели глин по отношению к метиленовому голубому позволяют спрогнозировать сорбционную способность исследуемых материалов к нефтепродуктам.
\end{abstract}

Natalia A. Medvedeva (Author ID in Scopus: 55164437300) - PhD in Chemistry, Associate Professor at the Department of Physical Chemistry (tel.: +007 902 478 43 11, e-mai: nata-kladova@yandex.ru).

Olga S. Siteva - Geologist (tel.: +007 90279628 18, e-mail: sisesin@rambler.ru)

Valeriy V. Seredin (Author ID in Scopus: 56974744000 ) - Professor, Doctor of Geology and Mineralogy, Head of the Department of Engineering Geology (tel.: +007 342 239 6439 , e-mail: seredin@nedra.perm.ru). The contact person for correspondence.

Медведева Наталья Александровна - кандидат химических наук, доцент кафедры физической химии (тел.: +0079024784311 , e-mai: nata-kladova@yandex.ru). Ситева Ольга Сергеевна - инженер-геолог (тел.: +007 90279628 18, e-mail: sisesin@rambler.ru).

Середин Валерий Викторович - профессор, доктор геолого-минералогических наук, заведующий кафедрой инженерной геологии (тел.: +007 3422396439 , e-mail: seredin@nedra.perm.ru). Контактное лицо для переписки. 


\section{Introduction}

Clays represent complex polymineral formations [1-3]. Their properties, including sorption, mainly depend on the lattice structure, mineral composition [4, 5], particle size distribution, [6], and environmental conditions [3, 5]. The mineral composition of clays manifests itself as energy on the surface of particles, whereas the particle size distribution manifests itself as the active surface area of particles [6]. These are exactly the two complex parameters which determine sorption activity of clays $[4,7]$.

Adsorption of substances from solutions at the "hard surface - water" phase boundary depends on the surface boundary electrical characteristics. Clay minerals are sources of constant and alternating surface charge [8]. Layered structures bear constant electric charge which is associated with the manifestation of heterovalent isomorphism in the lattice i.e. isomorphous replacement of $\mathrm{Si}$ with $\mathrm{Al}$ in a tetrahedral lattice and isomorphous replacement of $\mathrm{Al}$ with $\mathrm{Mg}$ in octahedrons. It does not depend on $\mathrm{pH}$ of the environment. Alternating charge, depending on $\mathrm{pH}$ of the environment, is located on lateral fractures of clayey crystallite, where hydroxyl groups are capable of proton adsorptiondesorption processes.

Thanks to their properties, clays can absorb inorganic ions, organic molecules, including dyes and petroleum products $[9,10]$, on the surface of a particle and in the interlayer space; thus, strong associations are formed which are kept on the surface by electrostatic force, as well as by Van der Waals forces [4].

In case of inorganic ions, the sorption capacity is expressed by determining the ion-exchange capacity and cation-exchange capacity. These values are not constant and depend on $\mathrm{pH}$, ionic force of the solution, and eluting ion. The highest values are common for montmorillonoids and the lowest values are common for kaolinites [8].

Determining clay-adsorption with the use of methylene blue (MB) dye is a wide-spread method that does not require special equipment [11-16]. In accordance with the chemical classification, MB is a dye belonging to the thiazine group. Its empirical formula is as follows: $\mathrm{C}_{16} \mathrm{H}_{18} \mathrm{~N}_{3} \mathrm{SCI}$ (its molecular weight is $319.85 \mathrm{~g} / \mathrm{mol}$ ) [17]. It is a cation type dye, which can be absorbed on a negatively charged surface of clay particles [18]. A MB molecule is rectangular in shape and its dimensions are as follows: $17.0 \AA \times 7.6 \AA \times 3.25 \AA$. Dye absorption on the surface of clay occurs in two ways: 1) cation exchange on the surface of aluminosilicate lattice; 2) attraction of dye molecules by Van der Waals forces or chemisorption (hydrogen bond) with the surface of $\mathrm{Si}-\mathrm{OH}$ and $\mathrm{Al}-\mathrm{OH}$ of the aluminosilicate lattice. [19]. In aqueous solutions organic dyes form associates of various complexities. This property allows us to use dye solutions to evaluate quality of sorbents with respect to various petroleum products.

In order to evaluate sorption activity of clays the following is performed: mechanical treatment, thermal modification [20-23], and chemical activation with the use of chemical agents such as acids [24-27], alkali [28], and salts combined with different exposure duration [29].

Compression under pressure is one of the mechanical methods $[6,30]$ of clay activation. As soon as clayey soils represent porous objects, their compression under pressure leads to changes in the structure. At low pressure clays are compacted as a result of reorientation of particles and reduction of pore volume [1]. The degree of orientation of particles of clays of different mineral composition differs at growing pressure. Kaolinite particles obtain more perfect orientation at a small pressure as compared to montmorillonite clay. The degree of perfection of particle orientation under pressure depends on the particle size, shape, friction rate on the surface, and hydrophilic behaviour. Bigger and asymmetrical particles are more oriented (kaolinite), than isodiametric (symmetric) and small (montmorillonite) particles.

At a compacting pressure of up to $100 \mathrm{MPa}$ there is an optimum amount of water and, respectively, a definite thickness of a hydrate film which correspond to building of a structure of the maximum strength. At the threshold pressure, squeezing-out of hydrate films and formation of point contacts start. Such threshold value for montmorillonite is $35 \mathrm{MPa}$ and that for kaolinite is $25 \mathrm{MPa}$ [31]. Compacting pressure increased up to $100 \mathrm{MPa}$ first leads to dispergation of structure forming aggregates and then to 
deformation of contact surfaces through some compaction of structure elements and squeezingout of hydrate films.

Based on the foregoing we may say that issues concerning evaluation of sorption properties of clays, subjected to mechanical activation by high pressure, are not studied enough. So, the purpose of the work is to determine sorption capacity of clayey soils exposed to high pressure when they encounter inorganic ions, methylene blue dye, and petroleum products.

\section{Objects of the research and research methods}

The objects of the research included the following clays of various crystalline structures: Lobanovsky montmorillonite and Chelyabinsk kaolin clays. Based on results of X-ray structure analysis [30] the montmorillonite clay consists of montmorillonite (75\%), kaolinite (3.6\%), quartz (11.4\%), albite (6.7 \%), and calc spar $(3.3 \%)$. The kaolin clay contains kaolinite (76.7 \%), montmorillonite (15.6\%), and quartz $(7.7 \%)$.

A high-pressure device [30] was used to transfer pressure to clay samples. Its working surfaces are made of hard-alloy material. The PLG-20 press was used as a loading device. Clay samples of $0.75 \mathrm{~cm}^{2}$ area were produced at the device in the pressure range of 0 to $700 \mathrm{MPa}$.

To determine sorption properties of clays the following products were used as sorbates: methylene blue dye, diesel fuel of L grade (diesel), engine oil MOTO 2T (EO), and gearbox oil TEP-15 (GO).

\section{Results of the research and discussion}

\section{Change of particle size distribution in clays} when clays are compressed. Particle size distribution of clays was determined by a laser diffraction analyzer ANALYSETTE 22 MicroTecplus [6, 32]. In the process of size analysis the following fractions were found: $\mathrm{F}_{<0.1}, \mathrm{~F}_{0.1-0.2}, \mathrm{~F}_{0.2-0.5}, \mathrm{~F}_{0.5-1}, \mathrm{~F}_{1-2}, \mathrm{~F}_{2-5}, \mathrm{~F}_{5-50}, \mathrm{~F}_{50-100}$, and $\mathrm{F}_{>100}$ (the index is a fraction particles size, $\mu \mathrm{m})$. It should be noted that according to GOST 25100-2011 [33], $\quad \mathrm{F}_{<0.1}-\mathrm{F}_{2}$ correspond to clay fraction, $\mathrm{F}_{2-50}$ correspond to pulverous fraction, $\mathrm{F}_{50-100}$ and $\mathrm{F}_{>100}$ correspond to sand fraction.
For the original samples not subjected to compression the following values were obtained:

- kaolinite: clay fraction $\left(\mathrm{F}_{<0.1}-\mathrm{F}_{2}\right) 52.36 \%$, pulverous fraction $\left(\mathrm{F}_{2-50}\right) \quad 47.62 \%$, and sand fraction $\left(\mathrm{F}_{50-100}\right.$ and $\left.\mathrm{F}_{>100}\right) 0.02 \%$;

- montmorillonite: 29.94; 70.06, and $0 \%$ respectively. Change in the particle size distribution after compression under pressure of 0 to $700 \mathrm{MPa}$ is shown in Fig. 1.
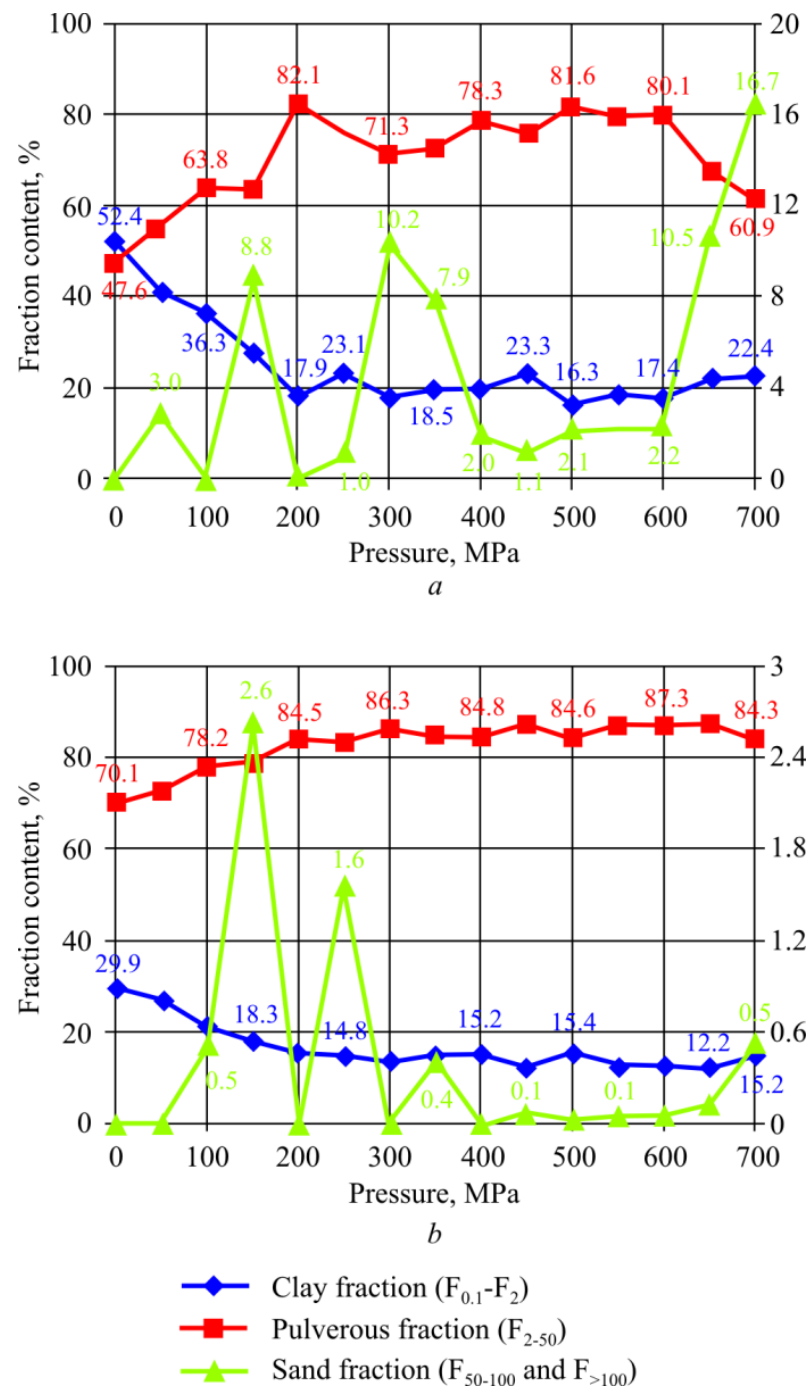

Fig. 1. Dynamics of changes in clay, pulverous, and sand fractions in the following tested clays: $a$ - kaolinite; $b$ - montmorillonite

The research conducted with clay samples after their compaction by pressure allowed us to find the following trends.

First, as clay compaction grows, the overall trend to the decrease of clay fractions and increase of pulverous fraction is observed. This is due to the formation of aggregates from the clay fraction of the soil. Assembling of fine colloids, resulting in 
aggregation, after exposure to pressure, is probably due to change in the interaction forces between particles. Coagulative contacts were formed between particles in original samples of clays at a pressure of $0 \mathrm{MPa}$. When pressure increases up to 150-200 MPa, transient contacts are formed. Coagulative forces, as well as chemical nature forces, which appear due to weakening and breaking of the hydrate film and formation of point contact, participate in their formation. When pressure exceeds $200 \mathrm{MPa}$ strong phase contacts of chemical and ionic-and-electrostatic nature are formed.

Second, in kaolin clay, changes in particle size distribution are more intense than in montmorillonite clay. This can be explained by the following: in kaolin clay the clay fraction content is higher than in argillite-like montmorillonite clay, so the specific surface in kaolin clay is bigger than that in montmorillonite clay. The bigger the specific surface is, the more contacts we have between particles. Hence, the process of aggregation of particles in kaolin clay is more intense than in montmorillonite clay.

Third, $P=150-200 \mathrm{MPa}$ pressure threshold interval was found based on the intensity of clay fractional formation. This can be explained by the fact that, in case of increase of pressure from 0 to $150-200 \mathrm{MPa}$ acting on clay samples, the clay samples' microstructure changes occur through change in types of contacts between particles: from coagulative to transient and phase. If the pressure exceeds 150-200 MPa, soil microstructure changes insignificantly, as soon as phase type of contacts is formed between particles.

Changes in clay particle size distribution lead to changes in the specific surface area of particles $\left(S_{\mathrm{s}}\right)$. It has been found that, if the pressure increases, the area of active surface of kaolin and montmorillonite clays decreases. In such case the biggest rate of the surface reduction is seen at a pressure under $150 \mathrm{MPa}$. If the pressure exceeds $150 \mathrm{MPa}$, the influence of the pressure on $S$ is less significant.

Clay sorption capacity research. Clay sorption capacity research was conducted in respect of the following: inorganic ions, organic ions, and petroleum products.

Determining clay sorption capacity. Inorganic ions. Clay sorption capacity was determined based on the fact that clays are H-cation exchangers, and so a hydrogen ion on the surface of clayey minerals may participate in exchange reaction with other cations. Adsorption of anions is weaker than adsorption of cations and it occurs on lateral fractures of clay particles. The area of fractures represents an insignificantly small area of the total surface area of particles in general [1]. That is why the sorption analysis was run only in respect of cations.

An important detail in the process of ion exchange of alkali metals is a significant influence of acidity of the environment $(\mathrm{pH})$. On this basis, adsorption of potassium chloride $\left(\mathrm{C}_{\mathrm{KCl}}=0.1 \mathrm{~mol} / \mathrm{l}\right)$ was determined by potentiometric titration method $[34,35]$. It is known that the ion exchange process on clayey minerals is thermodynamicallyreversible $[34,36]$. That is why in the process of studying the ion exchange on the surface of clays the time of ion exchange balance achievement is important. Values of the balanced condition in case of different cation exchange in different types of clayey minerals are not the same [37]. In some cases the balance is reached after some days (usually 2-3). Taking into account that fact, the time, needed for reaching the balance in kaolinite and montmorillonite in the presence of potassium chloride, was found and it amounted to $24 \mathrm{~h}$; the process of ion exchange was considered balanced when $\mathrm{pH}$ value did not change any more.

Based on titration experimental curves (Fig. 2) ion-exchange capacity was calculated $\left(\mathrm{QH}_{\mathrm{H}}^{+} / \mathrm{OH}^{-}\right)$ (mmol/g) using the following formula:

$$
Q_{\mathrm{H}^{+} / \mathrm{H}^{-}}=\frac{C\left(V-V_{0}\right)}{m},
$$

where $C$ is a titrant concentration $\left(C_{\mathrm{HCl}}\right.$ or $\left.C_{\mathrm{NaOH}}\right)$ $0.1 \mathrm{~mol} / \mathrm{l} ; \quad V$ and $V_{0}$ are titrant volumes in the presence of clay and without clay, $\mathrm{ml} ; m$ is a clay weight, $g$.

There are titration curves and ion-exchange capacity dependences on the solution $\mathrm{pH}$ in Fig. 2 and 3 for clays of different nature when they come in contact with dispersive medium.

Based on the obtained experimental results we can single out the following aspects characterizing exchange adsorption of clays depending on $\mathrm{pH}$ value. First, the type of ion exchange curves $\left(Q_{\mathrm{H}^{+} / \mathrm{OH}^{-}}=f(p H)\right)$ is determined by properties of functional (ionogenic) groups of clay minerals and 

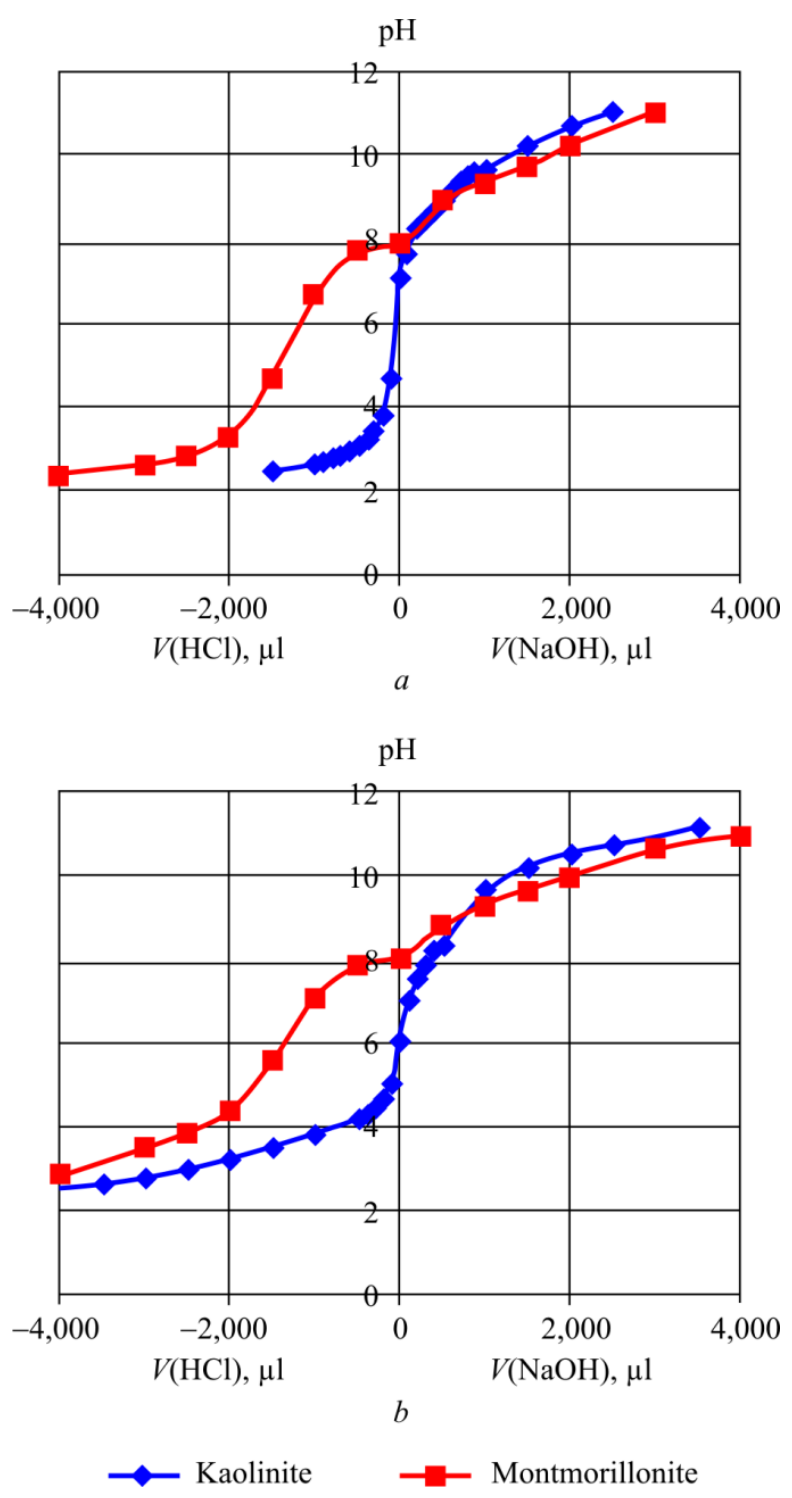

Fig. 2. Titration curves of kaolinite and montmorillonite dispersion at a pressure of $0(a)$ and $700 \mathrm{MPa}(b)$

it is specific to bi-functional ion-exchangers with a strong and weak acid group. Second, sorption behaviour of clays exposed to pressure significantly depends on the nature of a mineral (structure, composition). Thus, ion exchange capacity in respect of cations is higher for montmorillonite than that for kaolinite. This is explained by the fact that kaolinite interlaminar bonding is provided by molecular and hydrogenic forces the energy of which exceeds the hydration energy of interlaminar space, whereas bonding in montmorillonite is provided by molecular forces and cations located in the interlaminar space and this bonding is not sufficient to resist hydration, so the interlaminar space expands. Moreover, ionexchange capacity rate of kaolinite is higher than that of montmorillonite.
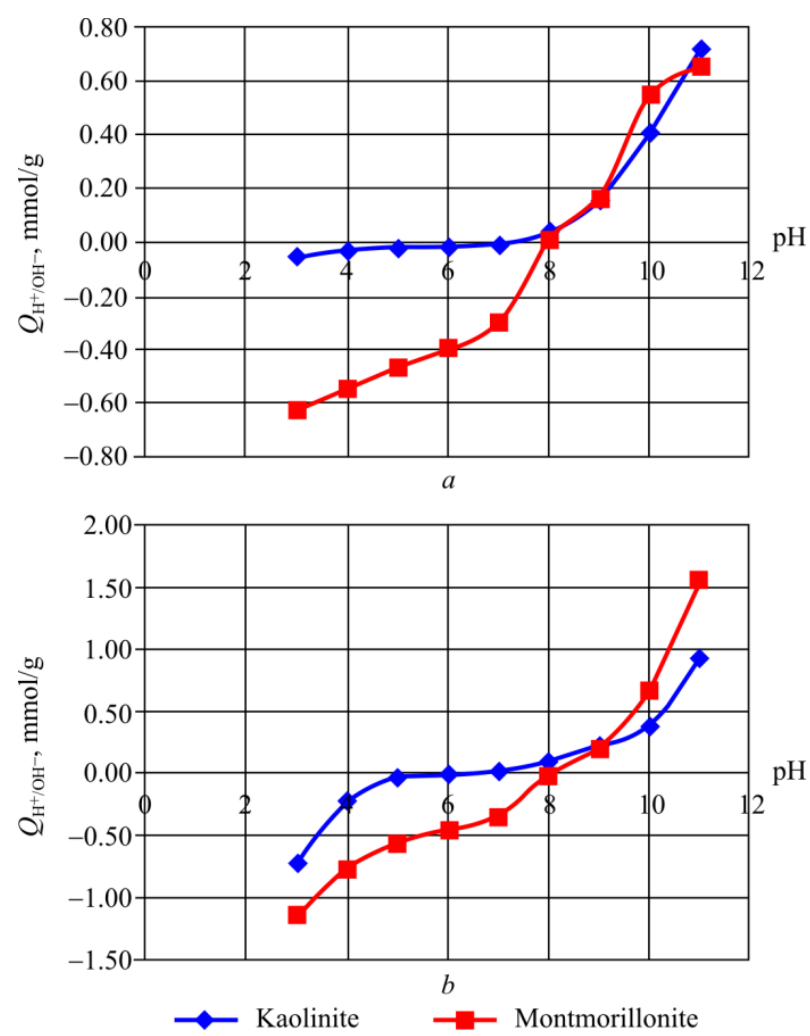

Fig. 3. Dependence of kaolinite

and montmorillonite ion-exchange capacity on $\mathrm{pH}$; applied pressure: $0(a)$ and $700 \mathrm{MPa}(b)$

Third, when the content of clay fraction in samples decreases and the pressure increases, the degree of dispersion of clays decreases, therefore, the ion-exchange capacity should decrease as well, but the test showed the contrary: when pressure increased, the degree of ion-exchange capacity grew in montmorillonite, as well as in kaolinite. This is explained by growing defects in the crystalline structure of clays and by appearance of new functional groups ("active centers"). Exchange processes in kaolinite take place mainly on lateral fractures of particles and they occur due to the presence of uncompensated valence links. Therefore, growing ion-exchange capacity can be explained by growing of the surface area of fractures of kaolinite as well.

Nevertheless, the content of clay fraction goes down, and the growing area of lateral faces of kaolinite can be explained only by simultaneous processes of fragmentation and aggregation of particles. In such case the area of basal faces goes down, whereas the area of lateral fractures goes up.

Determination of sorption capacity of clays. Methylene blue dye. Methylene blue dye was adsorbed in accordance with a method as per 
GOST 21283-93 [38]. Clay-adsorption value $(\mathrm{mg} / \mathrm{g})$ was determined based on the following formula:

$$
A=\frac{C \cdot V}{m},
$$

where $C$ is a $\mathrm{MB}$ dye solution concentration, $\mathrm{mg} / \mathrm{cm}^{3} ; V$ is a MB dye solution volume used for titration, $\mathrm{cm}^{3} ; m$ is a weight of a tested clay sample, g.

Change of montmorillonite and kaolinite sorption capacity in respect of MB dye depending on the pressure applied to samples is shown in Fig. 4.

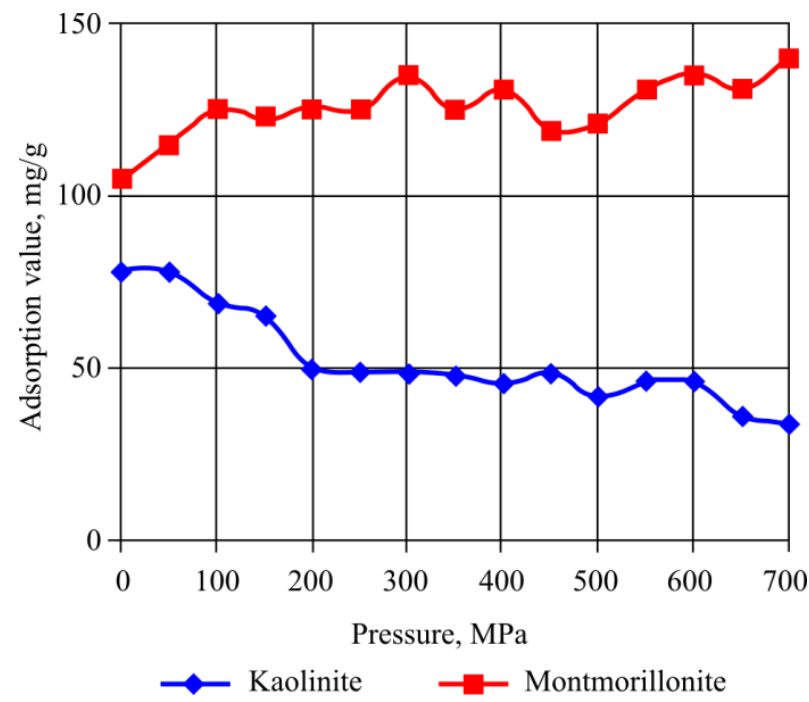

Fig. 4. Kaolinite and montmorillonite adsorption value change dynamics for methylene blue dye depending on the pressure applied

Adsorption value of kaolinite is significantly lower than that of montmorillonite, which is due to the sorption capacity of the latter in the interlaminar space [39]. At a pressure of $0-200 \mathrm{MPa}$ kaolinite demonstrates general drop of adsorption value from 80 to $50 \mathrm{mg} / \mathrm{g}$; after $200 \mathrm{MPa}$ this parameter does not change significantly. The content of clay fraction is directly related to kaolinite adsorption value at applied pressures.

Kaolinite adsorption value manifested in respect of $\mathrm{MB}$ dye decreases if pressure increases; at the same time its ion-exchange capacity grows. This is explained by the fact that, when pressure is applied, the charge value increases on the surface of kaolinite particles and this value is sufficient for the growth of sorption of inorganic ions, but insufficient to keep MB dye molecules on the surface of clay particles.
Original montmorillonite has higher sorption capacity which is due to expansion of the interlaminar space up to the dimension of intruding molecules [40, 41]. If pressure increases, the adsorption value of montmorillonite grows from 105 to $140 \mathrm{mg} / \mathrm{g}$ and it is inversely related to the content of clay fraction. Based on that we come to a conclusion that when the samples of clay are compacted under pressure, the area of defects on the surface of minerals increases and, consequently, new "active centers" appear on the surface of clay particles which are ready to adsorb MB dye.

Adsorption of petroleum products by clays. Samples of clays preliminary saturated with diesel fuel, engine oil, and gearbox oil for three days, were dried in an infrared thermogravimetric moisture meter MA35 at a temperature of $160{ }^{\circ} \mathrm{C}$. First, in the drying chamber the samples were weighed, and then the loss of weight was determined automatically by means of infrared rays, and, afterwards, the result was converted into moisture (petroleum product) content units with regard to the initial weight of each sample. The adsorption value $\mathrm{A}, \mathrm{mg} / \mathrm{g}$, was calculated based on the following formula:

$$
\mathrm{A}=\frac{\left(m_{1}-m_{2}\right) 1,000}{m_{2}},
$$

where $m_{1}$ is a weight of a clay sample saturated with a petroleum product before the beginning of drying, $g ; m_{2}$ is a weight of a clay sample after the test in the moisture meter, $\mathrm{g}$.

Change in montmorillonite and kaolinite sorption capacity manifested in respect of diesel fuel, engine oil, and gearbox oil depending on pressure is shown in Fig. 5. As an example the charts show the results obtained at the following pressures: 100, 300, and $700 \mathrm{MPa}$.

Based on the adsorption value change dynamics we see that kaolinite and montmorillonite demonstrate the maximum sorption capacity values in respect of diesel fuels in original samples (not exposed to pressure). Then adsorption drops sharply to $92-99 \mathrm{mg} / \mathrm{g}$ at a pressure of $100 \mathrm{MPa}$, and after that pressure there are no significant changes in adsorption.

During sorption of engine oil and gearbox oil by kaolinite, the biggest fluctuations of adsorption value are seen in the range before $200 \mathrm{MPa}$; at 
higher pressures the adsorption value changes within $40-60 \mathrm{mg} / \mathrm{g}$.
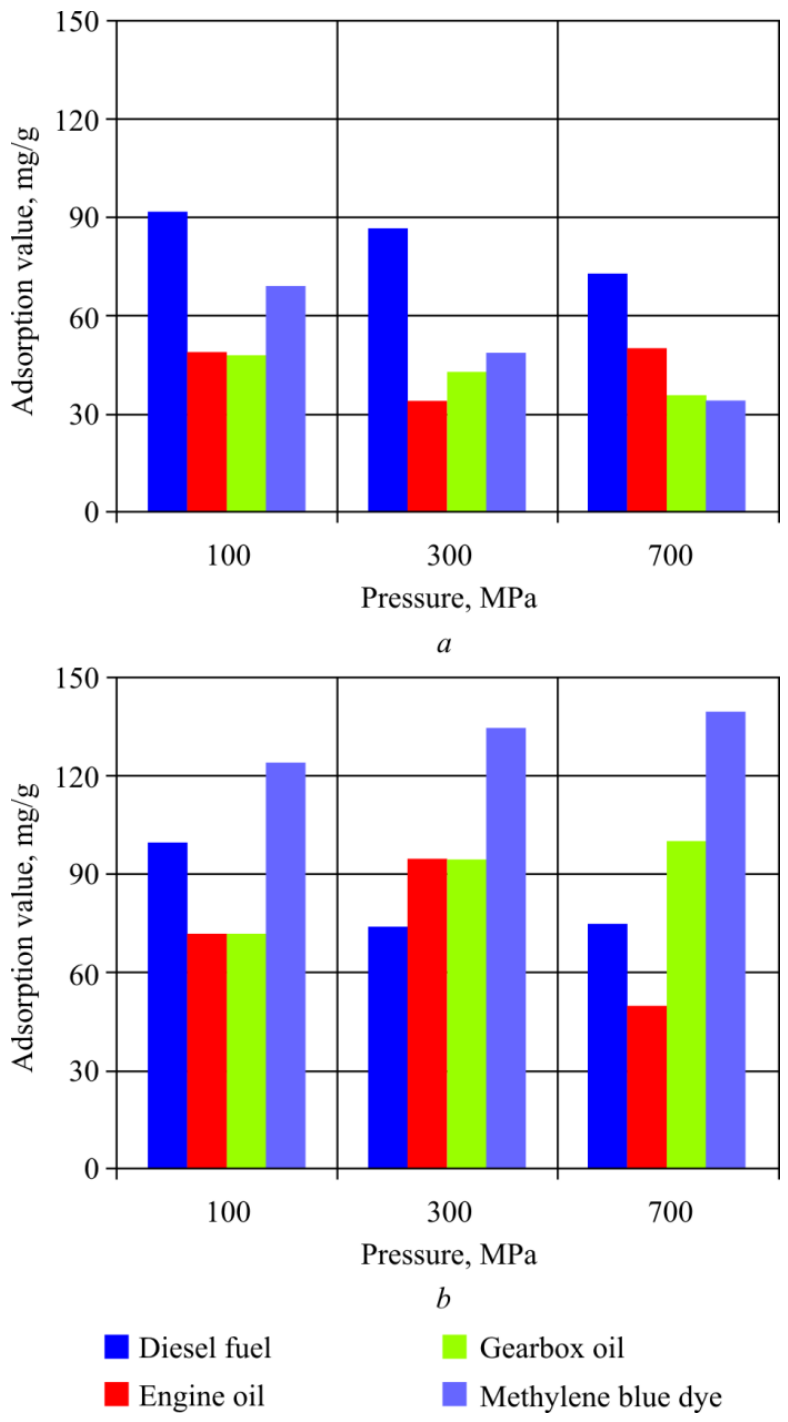

Fig. 5. Kaolinite ( $a$ ) and montmorillonite $(b)$ adsorption value change dynamics shown for petroleum products and $\mathrm{MB}$ dye at the following pressures: 100, 300, and $700 \mathrm{MPa}$

During sorption of engine oil by montmorillonite until a pressure of $400 \mathrm{MPa}$ the adsorption value increases up to $100 \mathrm{mg} / \mathrm{g}$ is observed; at higher pressures no trends are observed. During adsorption of gearbox oil by montmorillonite a general trend is seen manifesting itself in the growth of values from 70 to $120 \mathrm{mg} / \mathrm{g}$.

It should be noted that adsorption capacity has been studied with the use of a moisture meter the operating temperature of which does not exceed $160{ }^{\circ} \mathrm{C}$; at such temperature only fractions that boil at a temperature not exceeding $160{ }^{\circ} \mathrm{C}$ are evaporated from clay. Therefore, the chart does not show a complete picture due to the fact that samples still contain high-boiling components of petroleum products.

When we compared the test data for petroleum products and methylene blue dye (please see Fig. 5), we found the adsorption processes seen in the clay minerals to be similar.

\section{Conclusion}

1. The experiments show that, if the pressure applied to kaolinite and montmorillonite grows up to $700 \mathrm{MPa}$, there is a general trend towards decrease of the clay fraction content and increase of the pulverous fraction content.

2. Adsorption behaviour of clays exposed to pressure significantly depends on the mineral composition, particle size distribution, and crystalline structure defects. Kaolinite and montmorillonite ion-exchange capacity depends on the environmental acidity.

3. Kaolinite adsorption value for methylene blue dye goes down until a pressure of $200 \mathrm{MPa}$, which is explained by the clay fraction content, and it does not significantly change at a pressure of 200-700 $\mathrm{MPa}$. Montmorillonite adsorption value shows a general trend to growth.

4. Adsorption of petroleum products by kaolinite and montmorillonite is at the threshold level at a pressure of 100 and $400 \mathrm{MPa}$.

\section{References}

1. Osipov V.I., Sokolov V.N., Rumyantseva N.A. Mikrostruktura glinistykh porod [The microstructure of clay rocks]. Moscow, Nedra, 1989, 211 p.

2. Tarasevich Yu.I., Ovcharenko F.D. Adsorbtsiya na glinistykh mineralakh [Adsorption on clay minerals]. Kiev, Naukova dumka, 1975, 351 p.

3. Seredin V.V., Krasilnikov P.A., Medvedeva N.A. Izmenenie elektrokineticheskogo potentsiala glinistykh kolloidov v vodnoy i uglevodorodnoy sredakh [Variation of electrokinetic potential of clayey colloids in aquatic and hydrocarbon media]. Geoekologiya, inzhenernaya geologiya, gidrogeologiya, geokriologiya, 2017, no.1, pp.66-74.

4. Komarov V.S. Adsorbtsionno-strukturnye, fizikokhimicheskie i kataliticheskie svoystva glin belorussii [Adsorption-structural, physico-chemical and catalytic properties of clays of Belarus]. Minsk, Nauka i tekhnika, $1970,320 \mathrm{p}$.

5. Seredin V.V., Parshina T.Iu. Mass change of bound water in clays under compression. Perm Journal of 
Petroleum and Mining Engineering, 2017, vol.16, no.1, pp.23-32. DOI: 10.15593/2224-9923/2017.1.3

6. Seredin V.V., Rastegaev A.V., Medvedeva N.A., Parshina T.Yu. Vliyanie davleniya na ploshchad aktivnoy poverkhnosti chastits glinistykh gruntov [Influence of pressure on the active surface area of clay soil particles]. Inzhenernaya geologiya, 2017, no.3, pp.18-27. DOI: 10.25296/1993-5056-2017-3-18-27

7. Seredin V.V., Fedorov M.V., Lunegov I.V., Medvedeva N.A. Zakonomernosti izmeneniya sil adgezii na poverkhnosti chastits kaolinitovoy gliny, podverzhennoy szhatiyu [Regularities of adhesion forces changes on the surface of kaolinite clay particles subjected to compression]. Inzhenernaya geologiya, 2018, vol.13, no.3, pp.8-18. DOI: 10.25296/1993-5056-2018-13-3-8-18

8. Sokolova T.A., Trofimov S.Ya. Sorbtsionnye svoystva pochv. Adsorbtsiya. Kationnyy obmen [Sorption properties of soils. Adsorption. Cation exchange]. Uchebnoe posobie po nekotorym glavam khimii pochv. Tula, Grif i K, 2009, 172 p.

9. Kuznetsov F.M., Kozlov A.P., Seredin V.V., Pimenova E.V. Rekultivatsiya neftezagryaznennykh pochv [Reclamation of oil-contaminated soil]. Perm, 2003, 105 p.

10. Shuvalov Yu.V., Sinkova E.A., Kuzmin D.N. Ochistka gruntov ot zagryazneniya neftyu i nefteproduktami [Soil cleaning from pollution by oil and petroleum products]. Gornyy informatsionnoanaliticheskiy byulleten, 2004, no.12, pp.7-10.

11. Pham Till Hang, Brindley G.W. Methylene blue absorption by clay minerals. Determination of surface areas and cation exchange capacities (Clay-organic studies XVIII). Clays and Clay Minerals, 1970, vol.18, is.4, pp.203-212. DOI: 10.1346/CCMN.1970.0180404

12. Gürses et al. Determination of adsorptive properties of clay/water system methylene blue sorption. Journal of Colloid and Interface Science, 2004, vol.269, iss.2, pp.310-314. DOI: 10.1016/j.jcis.2003.09.004

13. Murat Türköz, Hasan Tosun. The use of methylene blue test for predicting swell parameters of natural clay soils. Scientific Research and Essays, 2011, vol.6(8), pp.1780-1792. DOI: $10.5897 /$ SRE10.629

14. Salwa D. Abayazeed, Essam El-Hinnawi. Characterization of Egyptian smectitic clay deposits by methylene blue adsorption. American Journal of Applied Sciences, 2011, vol.8(12), pp.1282-1286. DOI: 10.3844/ajassp.2011.1282.1286

15. Chiappone A., Marello S., Scavia C. Clay mineral characterization through the methylene blue test: comparison with other experimental techniques and applications of the method. Canadian Geotechnical Journal, 2004, vol.41(6), pp.1168-1178. DOI: 10.1139/T04-060

16. Gribanov E.N., Oskotskaya E.R., Kuzmenko A.P. Osobennosti stroeniya, morfologii i kislotno-osnovnykh svoystv poverkhnosti alyumosilikata Khotynetskogo mestorozhdeniya [Peculiarities of the structure, morphology, and acid-basic properties of the alumosilicate surface of hotynetsky deposits]. Kondensirovannye sredy $i$ mezhfaznye granitsy, 2018, vol.20, no.1, pp.42-49. DOI: $10.17308 / \mathrm{kcmf} .2018 .20 / 475$

17. Nikolskiy B.P., Grigorov O.N., Pozin M.E. et al. Spravochnik khimika [Chemist handbook]. Moscow, Goskhimizdat, 1971, vol.2, $1168 \mathrm{p}$.

18. Hills J.F., Pettifer G.S. The clay mineral content of various rock types compared with the methylene blue valu. Journal of Chemical Technology and Biotechnology, 1985, vol.35A, pp.168-180. DOI: 10.1002/jctb.5040350404

19. Yeliz Yukselen, Abidin Kaya. Suitability of the methylene blue test for surface area, cation exchange capacity and swell potential determination of clayey soils. Engineering Geology, 2008, vol.102, iss.1-2, pp.38-45. DOI: 10.1016/j.enggeo.2008.07.002

20. Tuchkova A.I., Tyupina E.A. Vliyanie temperatury aktivatsii bentonita na ego sorbtsionnuyu sposobnost $\mathrm{k}$ izvlecheniyu Cs-137 iz vakuumnykh masel [The influence of bentonite temperature activation on its sorption capacity in relation to Cs-137 extraction from the vacuum oils]. Uspekhiv khimii i khimicheskoy tekhnologii. Sbornik nauchnykh trudov, 2010, vol.XXIV, 7(112), pp.12-15.

21. Kara-sal B.K., Sapelkina T.V. Povyshenie adsorbtsionnykh svoystv glinistykh porod Tuvy V zavisimosti ot metodov aktivatsii [Improving the adsorption properties of clay rocks of Tuva, depending on the activation methods]. Aktualnye problemy sovremennoy nauki, 2012, no.5, pp.158-162.

22. Binnatova L.A. et al. Termoobrabotka bentonita i adsorbtsiya metilena golubogo [Heat Treatment of Bentonite and Adsorption of Methylene Blue]. Kondensirovannye sredy $i$ mezhfaznye granitsy, 2007, vol.9, no.2, pp.99-101.

23. Belchinskaya L.I. et al. Vliyanie termicheskogo modifitsirovaniya na adsorbtsionnye svoystva prirodnykh silikatov [The effect of thermal modification on the adsorption properties of natural silicates]. Sorbtsionnye $i$ khromatograficheskie protsessy, 2006, vol.6, iss.1, pp.80-81.

24. Kormosh E.V., Alyabeva T.M. Razrabotka effektivnykh sorbtsionno-aktivnykh materialov dlya ochistki stochnykh vod ot nefteproduktov [The development of effective sorption active materials for sewage water purification from oil product waste]. Uspekhi sovremennogo estestvoznaniya, 2016, no.5, pp.20-24.

25. Mostalygina L.V., Chernova E.A., Bukhtoyarov O.I. Kislotnaya aktivatsiya bentonitovoy gliny [Acid activation of bentonite clay]. Vestnik $Y u U r G U, 2012$, no.24, pp.57-61.

26. Kanygina O.N. et al. K voprosu o sorbtsionnoy ochistke vody montmorillonit soderzhashchey glinoy [On the issue of sorption purification of water montmorillonitecontaining clay]. Vestnik $O G U, 2014$, no.9(170), pp.160-163.

27. Vezentsev A.I., Korolkova S.V., Volovicheva N.A. Fiziko-khimicheskie kharakteristiki prirodnoy i modifitsirovannoy gliny mestorozhdeniya Polyana Belgorodskoy oblasti [Physical and chemical characteristics of natural and modified clay deposits of the glade Belgorod 
region]. Sorbtsionnye i khromatograficheskie protsessy, 2008, vol.8, iss.5, pp.790-795.

28. Tuchkova A.I., Tyupina E.A., Rakhimov M.G. Vliyanie shchelochnoy aktivatsii glinistykh mineralov na ikh sorbtsionnuyu sposobnost k izvlecheniyu Cs-137 iz otrabotavshego masla [The effect of alkaline activation of clay minerals on their sorption ability to extract Cs-137 from waste oil]. Uspekhi $v$ khimii $i$ khimicheskoy tekhnologii. Sbornik nauchnykh trudov, 2012, vol.XXVI, no. 6(135), pp.92-95.

29. Kurtukova L.V., Somin V.A., Komarova L.F. Issledovaniya po udaleniyu iz vody soley zhestkosti $\mathrm{s}$ primeneniem sorbentov na osnove mineralnykh volokon i bentonitovykh glin [Probes of a software to withdrawing from water of hardness salts $\mathrm{w}$ application of sorbents on the basis of mineral fibres and bentonitic clays]. Uspekhi sovremennogo estestvoznaniya, 2011, no.12, pp.29-31.

30. Seredin V.V., Rastegaev A.V., Galkin V.I., Parshina T.Yu., Isaeva G.A. Vliyanie davleniya i granulometricheskogo sostava na energeticheskuyu aktivnost glin [Influence of pressure and granulometric composition on the energy activity of clays]. Inzhenernaya geologiya, 2017, no.4, pp.62-71. DOI: 10.25296/1993-5056-2017-4-62-71

31. Nichiporenko S.P., Panasevich A.A., Minchenko V.V. et al. Strukturoobrazovanie $\mathrm{v}$ dispersiyakh sloistykh silikatov [Structure formation in dispersions of layered silicates]. Ed. S.P. Nichiporenko. Kiev, Naukova dumka, 1978, $202 \mathrm{p}$.

32. Laser particle sizer "Analysette 22" (NanoTec/MicroTec/XT): operating instructions. IdarOberstein, Germany: Fritsch GmbH, 2004, available at: https://www.johnmorrisgroup.com/Content/Attachments/1 2867/268095_manual_instr-John-Morris.pdf (accessed 01 June 2018).

33. GOST 25100-2011. Grunty. Klassifikatsiya (s popravkoy) [Soils. Classification (amended)]. Moscow, Standartinform, 2013, 45 p.
34. Toropova N.A. Praktikum po khimii kremniya i fizicheskoy khimii silikatov [Work book on silicon chemistry and physical chemistry of silicates]. Lvov, Izdatelstvo lvovskogo universiteta, 1965, $292 \mathrm{p}$.

35. Vasilev V.P. Analiticheskaya khimiya. Book 1: Titrimetricheskie i gravimetricheskiy metody analiza [Analytical chemistry. Book 1: Titrimetric and Gravimetric Analysis Methods]. Moscow, Drofa, 2004, 368 p.; Book 2: Fiziko-khimicheskie metody analiza [Physicfl and chemical methods of analysis]. Moscow, Drofa, 2004, 384 p.

36. Tang L., Sparks D.L. Cation-exchange kinetics on montmorillonite using pressure-jump relaxation. Soil Science Society of America Journal, 1993, vol.57, no.1, pp.42-46. DOI: 10.2136/sssaj1993.03615995005700010009x

37. Bhattacharyya K.G., Gupta S.S. Adsorption of a few heavy metals on natural and modified kaolinite and montmorillonite: A review. Advances in Colloid and Interface Science, 2008, no.140, pp.114-131. DOI: $10.1016 /$ j.cis.2007.12.008

38. GOST 21283-93. Glina bentonitovaya dlya tonkoy i stroitelnoy keramiki. Metody opredeleniya pokazatelya adsorbtsii i emkosti kationnogo obmena [Clay bentonite for fine and building ceramics. Methods for determining the adsorption index and cation exchange capacity]. Minsk, Izdatelstvo standartov, 1995, 8 p.

39. Seredin V.V., Rastegayev A.V., Panova E.G., Medvedeva N.A. Changes in physical properties of clay under compression. International Journal of Engineering and Applied Sciences, 2017, vol.4, no.3, pp.22.

40. Tarasevich Yu.I. Stroenie i khimiya poverkhnosti sloistykh silikatov [Structure and chemistry of the surface of layered silicates]. Kiev, Naukova dumka, $1988,248 \mathrm{p}$.

41. Aripov E.A., Agzamkhodzhaev A.A. Aktivnye tsentry montmorillonita i khemosorbtsiya [Active centers of montmorillonite and chemisorption]. Tashkent, Fan, 1983, $164 \mathrm{p}$.

\section{Библиографический список}

1. Осипов В.И., Соколов В.Н., Румянцева Н.А. Микроструктура глинистых пород. - М.: Недра, 1989. $-211 \mathrm{c}$.

2. Тарасевич Ю.И., Овчаренко Ф.Д. Адсорбция на глинистых минералах. - Киев: Наукова думка, 1975. $351 \mathrm{c}$.

3. Середин В.В., Красильников П.А., Медведева Н.А. Изменение электрокинетического потенциала глинистых коллоидов в водной и углеводородной средах // Геоэкология, инженерная геология, гидрогеология, геокриология. - 2017. - № 1. - С. 66-74.

4. Комаров В.С. Адсорбционно-структурные, физико-химические и каталитические свойства глин Белоруссии. - Минск: Наука и техника, 1970. - 320 с.

5. Середин В.В., Паршина Т.Ю. Изменение масс связанной воды в глинах при сжатии // Вестник
Пермского национального исследовательского политехнического университета. Геология. Нефтегазовое и горное дело. - 2017. - Т. 16, № 1. - С. 23-32. DOI: $10.15593 / 2224-9923 / 2017.1 .3$

6. Влияние давления на площадь активной поверхности частиц глинистых грунтов / В.В. Середин, А.В. Растегаев, Н.А. Медведева, Т.Ю. Паршина // Инженерная геология. - 2017. - № 3. - С. 18-27. DOI: 10.25296/1993-5056-2017-3-18-27

7. Закономерности изменения сил адгезии на поверхности частиц каолинитовой глины, подверженной сжатию / В.В. Середин, М. В. Федоров, И.В. Лунегов, Н.А. Медведева // Инженерная геология. - 2018. - Т. 13, № 3. - C. 8-18. DOI: 10.25296/1993-5056-2018-13-3-8-18

8. Соколова Т.А., Трофимов С.Я. Сорбционные свойства почв. Адсорбция. Катионный обмен: учеб. 
пособие по некоторым главам химии почв. - Тула: Гриф и К, 2009. - 172 с.

9. Рекультивация нефтезагрязненных почв: учеб. пособие / Ф.М. Кузнецов, А.П. Козлов, В.В. Середин, Е.В. Пименова. - Пермь, 2003. - 105 с.

10. Шувалов Ю.В., Синькова Е.А., Кузьмин Д.Н. Очистка грунтов от загрязнения нефтью и нефтепродуктами // Горный информационноаналитический бюллетень. - 2004. - № 12. - С. 7-10.

11. Pham Till Hang, Brindley G.W. Methylene blue absorption by clay minerals. Determination of surface areas and cation exchange capacities (Clay-organic studies XVIII) // Clays and Clay Minerals. - 1970. - Vol. 18, iss. 4. P. 203-212. DOI: 10.1346/CCMN.1970.0180404

12. Determination of adsorptive properties of clay/water system methylene blue sorption / Gürses [et al.] // Journal of Colloid and Interface Science. - 2004. - Vol. 269, iss. 2. - P. 310-314. DOI: 10.1016/j.jcis.2003.09.004

13. Murat Türköz, Hasan Tosun. The use of methylene blue test for predicting swell parameters of natural clay soils // Scientific Research and Essays. - 2011. - Vol. 6(8). P. 1780-1792. DOI: $10.5897 /$ SRE10.629

14. Salwa D. Abayazeed, Essam El-Hinnawi. Characterization of Egyptian smectitic clay deposits by methylene blue adsorption // American Journal of Applied Sciences. - 2011. - Vol. 8 (12). - P. 1282-1286. DOI: $10.3844 /$ ajassp.2011.1282.1286

15. Chiappone A., Marello S., Scavia C. Clay mineral characterization through the methylene blue test: comparison with other experimental techniques and applications of the method // Canadian Geotechnical Journal. - 2004. - Vol. 41(6). - P. 1168-1178. DOI: $10.1139 / \mathrm{T} 04-060$

16. Грибанов Е.Н., Оскотская Э.Р., Кузьменко А.П. Особенности строения, морфологии и кислотноосновных свойств поверхности алюмосиликата Хотынецкого месторождения // Конденсированные среды и межфазные границы. - 2018. - Т. 20, № 1. C. 42-49. DOI: $10.17308 / \mathrm{kcmf} .2018 .20 / 475$

17. Справочник химика / Б.П. Никольский, О.Н. Григоров, М.Е. Позин [и др.]. - М.: Госхимиздат, 1971. - T. 2. -1168 c.

18. Hills J.F., Pettifer G.S. The clay mineral content of various rock types compared with the methylene blue value // Journal of Chemical Technology and Biotechnology. - 1985. - Vol. 35A. - P. 168-180. DOI: $10.1002 /$ jctb.5040350404

19. Yeliz Yukselen, Abidin Kaya. Suitability of the methylene blue test for surface area, cation exchange capacity and swell potential determination of clayey soils // Engineering Geology. - 2008. - Vol. 102, is. 1-2. P. 38-45. DOI: 10.1016/j.enggeo.2008.07.002

20. Тучкова А.И., Тюпина Е.А. Влияние температуры активации бентонита на его сорбционную способность к извлечению Cs-137 из вакуумных масел // Успехи в химии и химической технологии: сб. науч. тр. - 2010. - Т. XXIV, 7(112). C. $12-15$.

21. Кара-Сал Б.К., Сапелкина Т.В. Повышение адсорбционных свойств глинистых пород Тувы в зависимости от методов активации // Актуальные проблемы современной науки. - 2012. - № 5. - С. 158-162.

22. Термообработка бентонита и адсорбция метилена голубого / Л.А. Биннатова [и др.] // Конденсированные среды и межфазные границы. 2007. - T. 9, № 2. - С. 99-101.

23. Влияние термического модифицирования на адсорбционные свойства природных силикатов / Л.И. Бельчинская [и др.] // Сорбционные и хроматографические процессы. - 2006. - Т. 6, Вып. 1. - С. 80-81.

24. Кормош Е.В., Алябьева Т.М. Разработка эффективных сорбционно-активных материалов для очистки сточных вод от нефтепродуктов // Успехи современного естествознания. - 2016. - № 5. - С. 20-24.

25. Мосталыгина Л.В., Чернова Е.А., Бухтояров О.И. Кислотная активация бентонитовой глины // Вестник ЮУрГУ. - 2012. - № 24. - С. 57-61.

26 К вопросу о сорбционной очистке воды монтмориллонитсодержащей глиной / О.Н. Каныгина [и др.] // Вестник ОГУ. - 2014. - № 9 (170). - С. 160-163.

27. Везенцев А.И., Королькова С.В., Воловичева Н.А. Физико-химические характеристики природной и модифицированной глины месторождения Поляна Белгородской области // Сорбционные и хроматографические процессы. - 2008. - Т. 8, Вып. 5. C. 790-795.

28. Тучкова А.И., Тюпина Е.А., Рахимов М.Г. Влияние щелочной активации глинистых минералов на их сорбционную способность к извлечению Cs-137 из отработавшего масла // Успехи в химии и химической технологии: сб. научн. тр. - 2012. T. XXVI, № 6(135). - С. 92-95.

29. Куртукова Л.В., Сомин В.А., Комарова Л.Ф. Исследования по удалению из воды солей жесткости с применением сорбентов на основе минеральных волокон и бентонитовых глин // Успехи современного естествознания. - 2011. - № 12. - С. 29-31.

30. Влияние давления и гранулометрического состава на энергетическую активность глин / В.В. Середин, А.В. Растегаев, В.И. Галкин, Т.Ю. Паршина, Г.А. Исаева // Инженерная геология. - 2017. - № 4. C. 62-71. DOI: 10.25296/1993-5056-2017-4-62-71

31. Структурообразование в дисперсиях слоистых силикатов / С.П. Ничипоренко, А.А. Панасевич, В.В. Минченко [и др.]; под общ. ред. С.П. Ничипоренко. Киев: Наукова думка, 1978. - 202 с.

32. Laser particle sizer "Analysette 22" (NanoTec/MicroTec/XT): operating instructions. IdarOberstein, Germany: Fritsch GmbH, 2004 [Электронный pecypc]. URL: https://www.johnmorrisgroup.com/ Content/Attachments/12867/26 8095_manual_instr-JohnMorris.pdf (дата обращения: 01.06.2018). 
33. ГОСТ 25100-2011. Грунты. Классификация (с поправкой). - М.: Стандартинформ, 2013. - 45 с.

34. Торопова Н.А. Практикум по химии кремния и физической химии силикатов. - Львов: Изд-во Львов. ун-та, 1965. - 292 с.

35. Васильев В.П. Аналитическая химия: в 2 кн.: Кн. 1: Титриметрические и гравиметрический методы анализа. - М.: Дрофа, 2004. - 368 с; Кн. 2: Физикохимические методы анализа. - М.: Дрофа, 2004. - 384 с.

36. Tang L., Sparks D.L. Cation-exchange kinetics on montmorillonite using pressure-jump relaxation // Soil Science Society of America Journal. - 1993. - Vol. 57, № 1. P. 42-46. DOI: 10.2136/sssaj1993.03615995005700010009x

37. Bhattacharyya K.G., Gupta S.S. Adsorption of a few heavy metals on natural and modified kaolinite and montmorillonite: A review // Advances in Colloid and Interface Science. - 2008. - № 140. - P. 114-131. DOI: 10.1016/j.cis.2007.12.008

38. ГОСТ 21283-93. Глина бентонитовая для тонкой и строительной керамики. Методы определения показателя адсорбции и емкости катионного обмена. - Минск: Изд-во стандартов, 1995. $-8 \mathrm{c}$.

39. Changes in physical properties of clay under compression / V.V. Seredin, A.V. Rastegayev, E.G. Panova, N.A. Medvedeva // International Journal of Engineering and Applied Sciences. - 2017. - Vol. 4, № 3. - P. 22.

40. Тарасевич Ю.И. Строение и химия поверхности слоистых силикатов. - Киев: Наукова думка, 1988. - 248 с.

41. Арипов Э.А., Агзамходжаев А.А. Активные центры монтмориллонита и хемосорбция. - Ташкент: Фан, 1983. - 164 c.

Please cite this article in English as:

Medvedeva N.A., Siteva O.S., Seredin V.V. Sorption ability of clays exposed to compression. Perm Journal of Petroleum and Mining Engineering, 2018, vol.18, no.2, pp.118-128. DOI: 10.15593/2224-9923/2018.4.2

Просьба ссылаться на эту статью в русскоязычных источниках следующим образом:

Медведева Н.А., Ситева О.С., Середин В.В. Сорбционная способность глин, подверженных сжатию // Вестник Пермского национального исследовательского политехнического университета. Геология. Нефтегазовое и горное дело. - 2018. - Т.18, №2. - C.118-128. DOI: 10.15593/2224-9923/2018.4.2 